\title{
The Characteristics, Detection and Control of Bacteriophage in Fermented Dairy Products
}

\author{
Sung-Il Ahn, Rehab A. Azzouny, Tran Thi Thanh Huyen', and Hae-Soo Kwak* \\ Department of Food Science and Technology, Sejong University, Seoul 143-747, Korea \\ ${ }^{I}$ Department of Civil and Environmental Engineering, Sejong University, Seoul 143-747, Korea \\ 발효유제품에서 박테리오파지의 특성, 검출과 제어 \\ 안성일 · 리합 아조니 · 트란 티 탄 후옌 ${ }^{1} \cdot$ 곽해수* $^{*}$ \\ 세종대학교 식품공학과, ${ }^{1}$ 토목환경공학과
}

\begin{abstract}
This study was to review the classification, detection and control of bacteriophage in fermented dairy products. Bacteriophage has lytic and/or lysogenic life cycles. Epidemiologically speaking, detected major phages are c2, 936 and p335. Among them p335 has been the largest concern in dairy industry. Traditionally, various analytical technologies, such as spot, starter activity, indicator test, ATP measurement and conductimetric analysis, have been used for the phage detection. In recent years, advanced methods such as flow cytometric method, petrifilm, enzyme linked immunosorbent assay (ELISA) and multiflex PCR diagnostic kit have been deveoloped. The phage contamination has been controlled by using heat, highpressure treatment, and the combinations of heat and pressure, and/or chemical. Also some starter cultures with phage-resistant character have been developed to minimize the concentration of phages in dairy product. Bacteriophage inhibition media such as calcium medium was also mentioned. To prevent the contamination of bacteriophage in dairy industry, further researches on the detection and control of phage, and phage resistant starters are necessary in the future.
\end{abstract}

Key words : bacteriophage, classification, detection, control, dairy products

\section{Introduction}

Fermented dairy foods offer unique opportunities and challenges in nutrition and health that are unavailable in other foods (Sellars, 1981). Consumers now realize the importance of these foods for maintaining high nutrition and health (Sellars, 1981).The success of the fermentation process depends primarily on the acid production of the starter culture. It is of course difficult to make good cheese unless the starters give consistently uniform acid production, and when the required acidity is achived it can be considered the question of flavor at maturity (Lawrence et al., 1978).

Lactic acid bacteria (LAB), such as lactococci, lactic streptococci and lactobacilli, are commonly used on an

*Corresponding author : Hae-Soo Kwak, Department of Food Science and Technology, Sejong University, Seoul 143-747, Korea. Tel: 82-2-3408-3226, Fax: 82-2-3408-4319, E-mail: kwakhs@sejong.ac.kr industrial scale for the production of fermented foods, such as cheese and yogurt (McGrath et al., 2004a). The susceptibility of these bacteria to infection by bacteriophages that are omnipresent in the dairy environment can have serious economic consequences for the dairy industry (Binetti et al., 2005).

Bacteriophages cause lysis of the starter bacteria and can lead to slow or failed milk acidification and the concomitant economic loss in the dairy industry. The problem is the difficulty of bacteriophages eradication from dairy plant. They resist during pasteurization and have short latent period. Once they emerge in a vat, they propagate throughout the dairy plant (Szczepanska et al., 2007). The exact origin of bacteriophages is not yet known (Madera et al., 2004). Only raw milk and the lysogenic starter culture are the clearly identified source (Szczepanska et al., 2007; Josephsen and Neve, 2004; Bruttin et al., 1997; Brüssow et al., 1994). In the dairy industry, the phage ecology is dominated by three phage 
species (McGrath et al., 2004a). The early detection of bacteriophages is of great importance as lactococcal phage population level of $10^{5}$ to $10^{7} \mathrm{PFU} / \mathrm{mL}$ in starter media or milk is an indication of a potential problem (Svenson and Christiansson, 1991).

In this review, different techniques of detection and the future requirement to fulfill the dairy industry requirements are discussed. The different treatments to control bacteriophages are also mentioned. The review is covering most of the required information to give the reader a whole picture of the bacteriophage classification, origin, life cycle, epidemiology and research future trend for the early detection as well as the bacteriophage control in the dairy plant.

\section{Classification}

Different classifications have been proposed to offer reliable criteria for bacteriophage classification (Sanlibaba and Akçelik, 2005). Traditionally bacteriophages are classified by morphology, host range and serology. Recently, DNA and protein information of the bacteriophages is used for the classification.

\section{Morphology}

It is a classical method for bacteriophage classification relying on physical shape basis. By direct microscopic examination, bacteriophages are classified on the basis of head size and shape (Jarvis, 1989). All known phages of lactic acid bacteria belong to the order caudovirales (tailed phages) (Brüssow and Hendrix, 2002), where they are further subdivided on the basis of tail morphology into 3 morphotypes, Myoviridae (A) which exhibit contractile tails, Siphoviridae (B) which have non-contractile tails and Podoviridae (C) which have short non contractile tails (McGrath et al., 2004a). These three families are further subdivided on head size and shape into isometric, small prolate and large prolate (elongated) heads to morphotypes 1, 2 and 3, respectively (Josephsen and Neve, 2004). The majority of phages classified into date that infect lactococcal, Lactobacillus species belong to the Siphoviridae B1 or B2 morphotypes. However, the bacteriophages attacking Streptococcus thermophilus are only reported to have the B1 Siphoviridae morphotype (McGrath et al., 2004a).

\section{Host range}

The phage infection process requires a phage receptor on the bacterial surface and a receptor binding protein
(RBP) located on the distal part of phage tail. The infection starts after a specific binding between RBP and the phage receptor (Duplessis et al., 2006). This determines the host range of the bacteriophages and modification to any of those structure may affect phage host interaction (Duplessis et al., 2006). Variability of the host range among different bacteriophages is well reported (Daly, 1983; Heap and Jarvis, 1980; Henning et al., 1986). This may be due to phage evolution by either mutation or recombination events or to a change in the bacterial sensitivity to phages (Jarvis, 1989).

The classification based on host range may have advantages on the applied view point i.e. selection of starter culture strain but it is of little taxonomic value as they do not relate to other classification schemes (McGrath et al., 2004a). For example, it was reported that $S$. thermophilus phage with similar host ranges showed limited DNA homology whereas those with higher DNA homology exhibited a completely different lytic spectrums (Mata and Ritzenthaler, 1988).

\section{Serology}

In 1921, Bordet and Ciuca showed that blood sera of rabbits previously injected with active bacteriophage filtrates contained antibodies (antiphage) which neutralized the activity of bacteriophage. Since then serological methods have been used to classify bacteriophages (Wilkowske et al., 1954). After Nichols and Hoyle (1949) first classified lactic Streptococcus bacteriophages into three serological groups, different attempts have been made to serologically classify $S$. thermophilus and lactococcal bacteriophages (Mata and Ritzenthaler, 1988; Brüssow et al., 1994; Jarvis 1989; Kivi et al., 1987). A serious drawback of this method was that it was based on differences in antigenic properties exposed on the surface of the virus which only indicated an expressed small part of the genome (McGrath et al., 2004a). This disadvantage hindered the development of a sensitive detection method.

\section{Structural protein profile}

The structural protein profile has been commonly used to classify $S$. thermophilus bacteriophages and was found to generally agree with other schemes (McGrath et al., 2004a). Phages from the same species have nearly the same morphology, share strong DNA homology and exhibit similar structural protein profiles (Jarvis et al., 1991). While most of the small isometric headed phages have one major structural protein, the large isometric 
and prolate headed phages have in common at least three major structural proteins (Moineau et al., 1992; Prevots et al., 1990; Braun et al., 1989; Powell et al., 1989). Major proteins are used to designate the protein that is in high concentration in the phage structure while minor proteins are numerous but of lower abundance. It was reported that there was a correlation between the method of DNA packaging i.e. pac or cos-type and the number, and type of structural proteins for both S. thermophilus and Lactobacillus delbruekii phages (Le Marrec et al., 1997; Forsman and Alatossava, 1991).

\section{DNA homology}

The development of an ordered taxonomy is hindered by the mosaic nature of bacteriophage genome (McGrath et al., 2006). Thus classification of LAB phages based on DNA homology evaluated the entire genome for a repeated small portion (McGrath et al., 2004b). This specific portion of the phage genome may encode the structural gene (McGrath et al., 2004b). On the basis of DNA, DNA hybridization studies of twelve genetically distinct lactococcal phage species have been defined (Jarvis et al., 1991). Based on repeated reports, all known S. thermophilus phages exhibit DNA homology (Quiberoni et al., 2003; Brüssow and Bruttin, 1995; Benbadis et al., 1990) and more closely related to one another unlike Lactococcus lactis phages (Le Marrec et al., 1997; Fayard et al., 1993; Neve et al., 1989).

\section{Origin}

The origins of the phages that colonizes the dairy plants are not fully answered (Madera et al., 2004). Different hypotheses have been attributed to describe the origin of bacteriophages in dairy plant. Some of them are attributed to natural widespread as dust-born infection (Whitehead 1953), the non-sterile environment inside the factory i.e. air, appliance, workers, large exposed area during cheese production (Szcepanska et al., 2007), and whey contamination (Dupont et al., 2005; McIntyre et al., 1991; Whitehead, 1953). The raw milk and the lysogenic starter culture are now clearly identified to be the main origin of phages in dairy plant (Fig. 1) (Szcepanska et al., 2007; Josephsen and Neve, 2004; Bruttin et al., 1997; Brüssow et al., 1994). Once an empty vat or a failure in fermented batch occurs, the infection with the virus is widespread throughout the dairy plant (Szcepanska et al., 2007). Their short latent period and resistance to pasteurization hinder their complete eradication from dairy plant.

\section{Life Cycle}

Bacteriophages are basically classified into virulent and temperate phage, and each has two types of life cycle, so called lytic and lysogenic. Lytic cycle is the process which a number of phages are released when lactic acid bacteria as a host cell is destroyed by their off-springs. Lysogenic cycle is the process which host cell infected

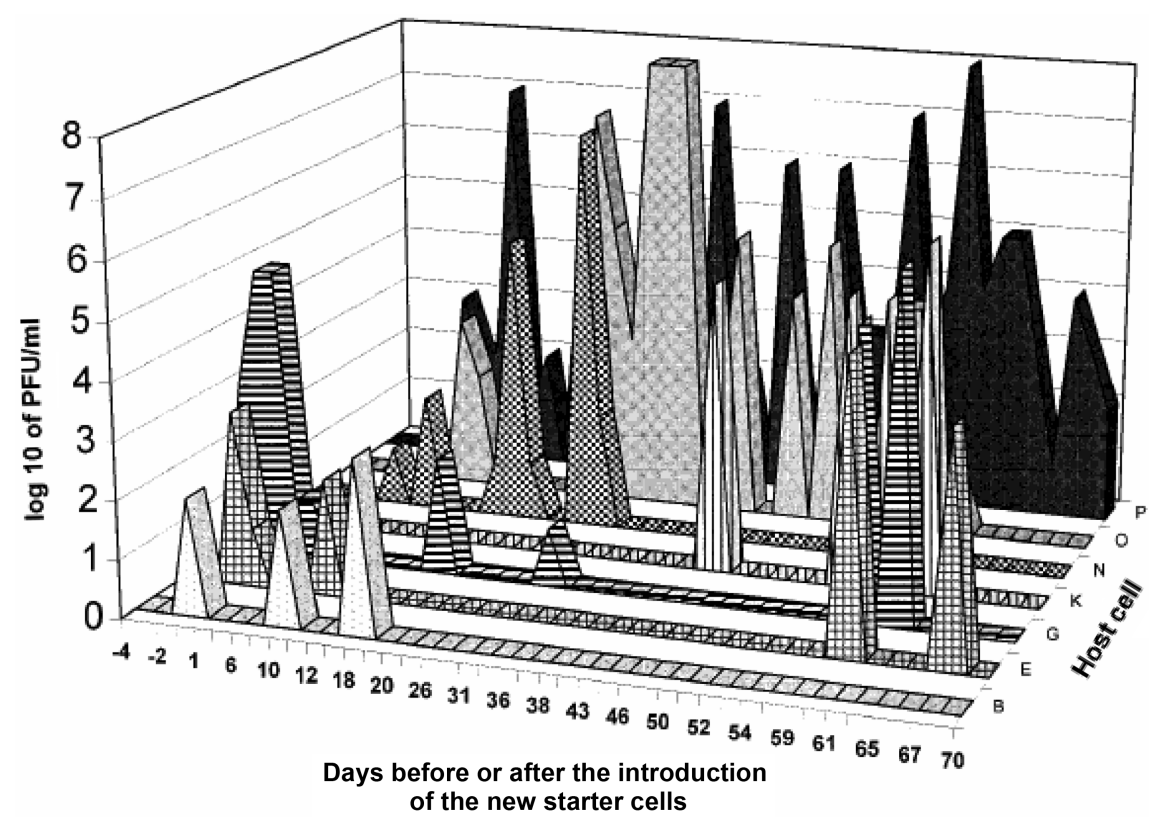

Fig. 1. The bacteriophages count ( $y$ axis) versus days ( $X$ axis) before (-ve numbers) introduction of new starter strains and after (+ve numbers). S. thermophillus starter strain types (Z axis) (Bruttin et al., 1997). 
with phage grows and divides into two host cells, and the host cell produces phages under specific condition such as UV radiation. Lytic cycle of phages are more harmful than lysogenic in dairy industry (Bush, 2002; Campbell and Reece, 2001).

Lytic cycle is started from attachment of bacteriophage on the host cell. The phage does not randomly attach to the surface of the host cell. They use specific surface structure called receptor site and use liposaccharide or protein of cell wall as their receptor. After phages attach on the host cell, they make a hole on the surface of the cell and inject their DNA into the cell. The host cell then synthesizes proteins for producing the phages at the same time. Lytic enzymes destroy rapidly the cell wall of the cell to release progeny phage after assembling phage particles (Nelson et al., 2006). The process above could be one cycle of lytic bacteriophage. Since the reproduction of this cycle is rapid, the contamination of the phages in the dairy plants is vulnerable.

A lot of phages related to starter culture are tracked in lysogenic cycle. When the host cells are infected, the last phase of their replications destroy all host cells. So, there is a risk that phages are exposed to environmental hazard for months or years. Lysogenic phage favors lysogenic cycle to avoid the above situations. Every cell infected by bacteriophage can grow and divide cell in lysogenic cycle for a long time (Prescott et al., 2002). The cell infected by bacteriophage can produce off-spring phages and be destroyed under specific condition such as UV radiation. When lysogenic bacteriophages are in starter culture more than $10^{6} \mathrm{PFU} / \mathrm{mL}$, there is a decrease of acid production by lactic acid bacteria, which is critical on cheese curd formation.

\section{Epidemiology}

Three phage species such as c2, 936 and p335 represent the majority of detected phages (McGrath et al., 2004a). In the reports from European countries, New Zealand, United States and Canada, 936 types of lactococcal phage were found to dominate (Fig. 2, Table 1) (Szcepanska et al., 2007; Bissonnette et al., 2000; Moineau, 1996). Dif-

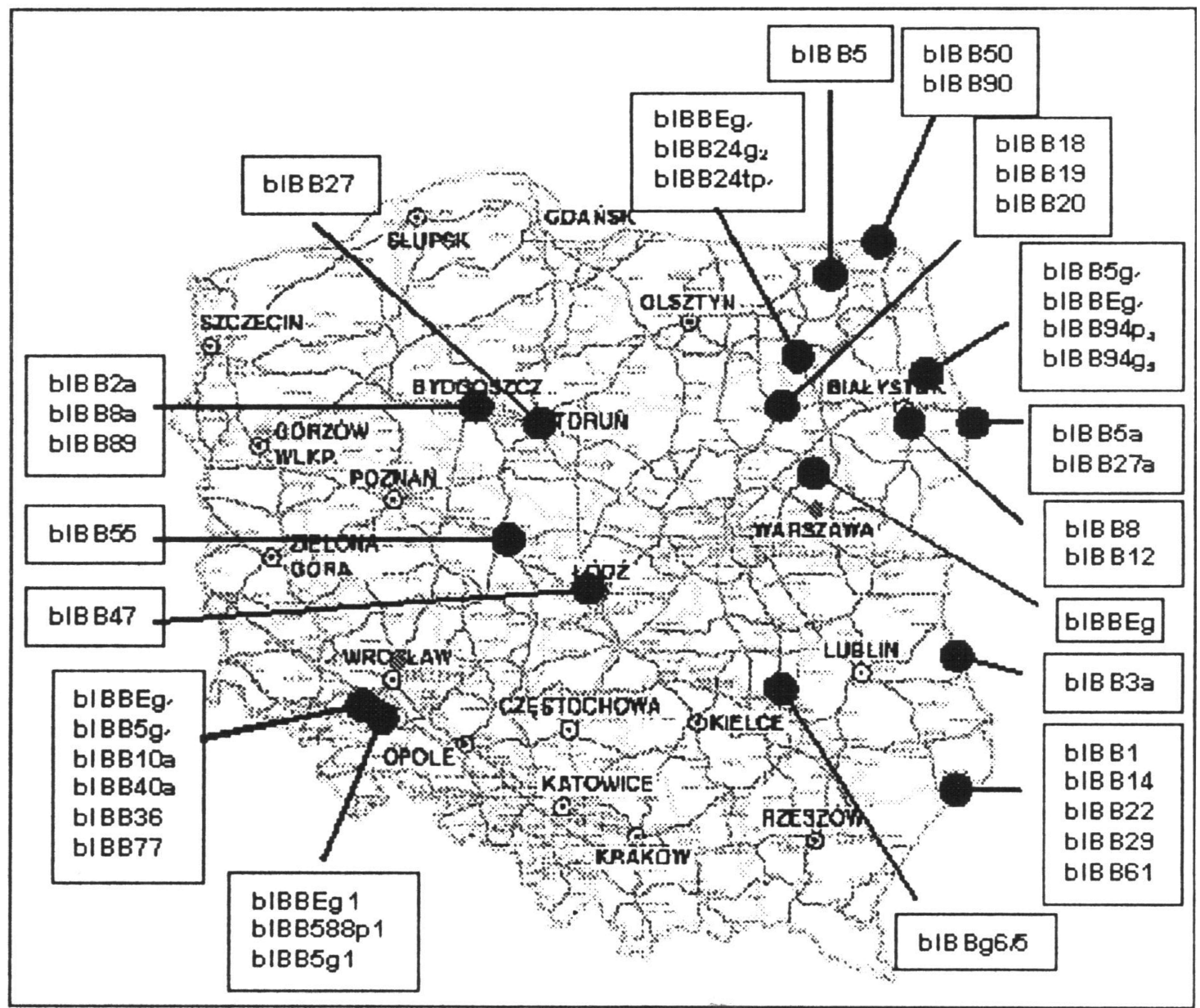

Fig. 2. Geographical distribution of virulent lactococcal phages in dairy environment in Poland (Szcepañska et al., 2007). 
Table 1. L. lactis strain sensitivity towards isolated phages (Szcepanska et al., 2007)

\begin{tabular}{|c|c|c|c|c|c|c|c|c|c|c|c|c|c|c|c|c|}
\hline \multirow[b]{2}{*}{ Phage } & \multirow{2}{*}{$\begin{array}{c}\text { Phage } \\
\text { type }\end{array}$} & \multicolumn{15}{|c|}{ Bacterial strain } \\
\hline & & $\begin{array}{l}\text { IBB } \\
094\end{array}$ & $\begin{array}{c}\text { IBB } \\
1767 \mathrm{~B}\end{array}$ & $\begin{array}{c}\text { IBB } \\
1772 B\end{array}$ & $\begin{array}{c}\text { IBB } \\
1780 \mathrm{~B}\end{array}$ & $\begin{array}{c}\text { IBB } \\
1782 B\end{array}$ & $\begin{array}{c}\text { IBB } \\
1783 B\end{array}$ & $\begin{array}{c}\text { IBB } \\
1784 \mathrm{~B}\end{array}$ & $\begin{array}{c}\text { IBB } \\
1787 \mathrm{~B}\end{array}$ & $\begin{array}{c}\text { IBB } \\
1788 \mathrm{~B}\end{array}$ & $\begin{array}{c}\text { IBB } \\
1791 B\end{array}$ & $\begin{array}{c}\text { IBB } \\
\text { 1793B }\end{array}$ & $\begin{array}{c}\text { IBB } \\
1794 \mathrm{~B}\end{array}$ & $\begin{array}{c}\text { IBB } \\
1796 \mathrm{~B}\end{array}$ & $\begin{array}{c}\text { IBB } \\
1800 \mathrm{~B}\end{array}$ & $\begin{array}{c}\text { IBB } \\
1807 \mathrm{~B}\end{array}$ \\
\hline bIBBg6/5 & $\mathrm{c} 2$ & & & & & & & & & & & & & & & + \\
\hline bIBB88P ${ }_{1}$ & $\mathrm{c} 2$ & & & & & & & & & & & & & + & & \\
\hline${\mathrm{bIBB} 94 \mathrm{P}_{4}}_{4}$ & $\mathrm{c} 2$ & + & & & & & & & & & & & & & & \\
\hline bIBB $94 g_{5}$ & c2 & + & & & & & & & & & & & & & & \\
\hline bIBB24g 2 & $\mathrm{c} 2$ & & & & & & & & & & & + & & & & \\
\hline $\mathrm{bIBB} 24 \mathrm{tp}_{1}$ & 936 & & & & & & & & & & & + & & & & \\
\hline bIBB5g $_{1}$ & 936 & & & & & & & & & & & + & & & & \\
\hline bIBBEg $_{1}$ & 936 & & & & & & & & & & & + & & & & \\
\hline bIBB2a & 936 & & & & & & & & + & & & & & & & \\
\hline bIBB 3a & 936 & & & & & & & & + & & & & & & & \\
\hline bIBB 5a & 936 & & & & & & & & + & & & & & & & \\
\hline bIBB 8a & 936 & & & & & & & & & & & + & & & & \\
\hline bIBB 10a & 936 & & & & & & & & & & & + & & & & \\
\hline bIBB 40a & 936 & & & & & & & & & & & + & & & & \\
\hline bIBB 1 & 936 & & & & + & & & & & & + & & & & & \\
\hline bIBB 5 & 936 & & & & + & & & & & & + & & & & & \\
\hline bIBB 8 & 936 & & & & + & & & & & & + & & & & & \\
\hline bIBB 12 & $\mathrm{c} 2$ & & & & & & & & + & & & & & & & \\
\hline bIBB 14 & $\mathrm{c} 2$ & & & & & & & + & & & & & & + & & \\
\hline bIBB 18 & $\mathrm{c} 2$ & & & & & & & + & & & & & & + & & \\
\hline bIBB 19 & c2 & & & & & & & + & & & & & & + & & \\
\hline bIBB 20 & $\mathrm{c} 2$ & & & & & & & + & & & & & & + & & \\
\hline bIBB 22 & $\mathrm{c} 2$ & & & & & & & + & & & & & & + & & \\
\hline bIBB 27 & $\mathrm{c} 2$ & & & & + & & & + & & & & & & + & & \\
\hline bIBB 27a & c2 & & & & & & & & & & & & & + & & \\
\hline bIBB 29 & 936 & & & & & & & + & & & & + & & + & & \\
\hline bIBB 36 & $\mathrm{c} 2$ & & & + & & & & & & & & & & & & \\
\hline bIBB 47 & 936 & & & & + & & & & & & & & & & & \\
\hline bIBB 50 & 936 & & & & + & & & & & & & & & & & + \\
\hline bIBB 55 & $\mathrm{c} 2$ & & & & & & & & & & & & & & & + \\
\hline bIBB 61 & c2 & & & & & + & & & & & & & & & & \\
\hline bIBB 77 & $\mathrm{c} 2$ & & & & & + & & & & & & & & & & \\
\hline bIBB 89 & $\mathrm{c} 2$ & & + & & & & & & & & & & & & & \\
\hline bIBB 95 & $\mathrm{c} 2$ & & & & & & & & & & & & & + & & \\
\hline
\end{tabular}

ferently in Germany, the dominating phages were c2 type while in Denmark the p335 phage was prevalent (Josephsen et al., 1999). In the last 10 years, p335 type phage has been encountered with higher frequency and it was proposed that numbers of this species will be the dominant phage type in the dairy industry (Josephsen and Neve, 2004). Some specific strains of Lactobacillus casei and paracase $i$ with probiotic activity are widely used industri- ally for the production of yogurt and cheese. It was reported that the first phage $(\varphi \mathrm{MLC}-\mathrm{A})$ was isolated in South America for the probiotic strain (Capra et al., 2006).

\section{Detection}

Phage monitoring is critically important in dairy indus- 
try, especially in cheese plant (Brüssow et al., 1994). Cheese making is a non-sterile process with high exposure to the plant environment. Raw or pasteurized milk is used in cheese manufacturing and many phages will resist pasteurization (Madera et al., 2004). Since a large dairy plant can process more than 500 tons of milk per day, a phage problem can lead to great economic loss (Binetti et al., 2005). A potential problem in a fermented batch is likely to occur if lactococcal phages exist in a population level of $10^{5}$ to $10^{7} \mathrm{PFU} / \mathrm{mL}$ in starter media or milk as this phage titer is able to retard milk acidification (Svenson and Christiansson, 1991). The correct and rapid identification of bacteriophages potentially able to attack starter cultures allow a prompt decision regarding the destination of contaminated milk (Del Rio et al., 2007). The contaminated milk could be used for process that does not require starters or processes that uses starter cultures insensitive to the phage detected i.e. the milk could undergo UHT to be used as drinking milk or used for yogurt production (Del Rio et al., 2007).

Phages can be detected in various ways. The traditional methods are spot test, starter activity test, indicator test (Valles, 1955), ATP measurement (Champiat et al., 1988) and conductimetric analyses (Fig. 3) (Svensson, 1994). These traditional test proved to have different disadvantages; they are time consuming and the majority rely on the availability of single indicator strain which is not possible in cheese manufacture that rely on mixed strain culture (Brüssow et al., 1994). Also these methods don't provide any information about the phage species causing the fermentation delay (Dupont et al., 2005). Most impor-

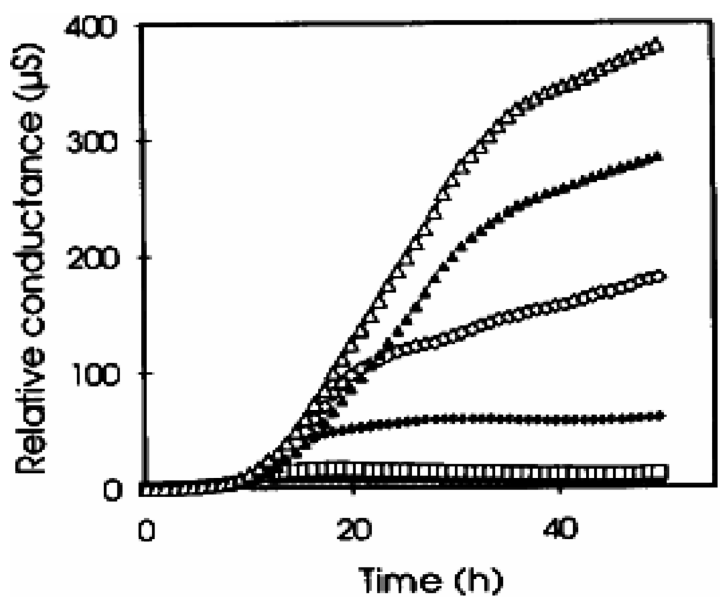

Fig. 3. Conductance change of starter strain SMR S19 grown in reconstituted milk at $20^{\circ} \mathrm{C}$ in the presence of various amounts of bacteriophages $(\triangle)$ Control, $(\triangle) 1$ PFU, $(\diamond) 10$ PFU, $(\diamond) 100$ PFU, ( $\square) 1000$ PFU, ( $)$ 10,000 PFU (Svensson, 1994). tantly, the traditional methods applied are indirect as they measure the metabolic activity of the starter culture inhibited by the phages, so a slow metabolic activity of the starter can lead to false positive results (Moineau et al., 1993). A flow cytometric method was also adopted in 2007 by Michelsen and co-workers (Fig. 4). Although the method can be performed in real time during the industrial process, it depends only upon the amount of infected cells rise independently of which type of phage has infected the culture. This doesn't allow a decision based on the results obtained to take any accurate decision i.e. the choice of the starter culture strain insensitive to the phage detected. Same disadvantages were observed for the petrifilm assay conducted in 2008 by Tseng and Hicks. The test is based upon the conventional method of phage enumeration where it measures the phage directly by its ability to lyse infected cells in a gel and so giving rise to plaques. The test is simple, as stated by the author, although many precautions for accurate results are required. Therefore, rapid, sensitive and reliable techniques are required for the detection of bacteriophages as they are related to a subsequent decision regarding the control measures and the fate of contaminated milk.

Immunological as well as molecular techniques are the most developing research until now due to their detection time, sensitivity and ability to identify the bacteriophage strains. For the immunological technique; an enzyme linked immunosorbent assay (ELISA) for the specific detection of 936, p335 and c2 phages was developed (Azaiez et al., 1998; Moineau et al., 1993). In these assays, antibodies against the major capsid protein for p335 and c2 phage were used but for lactococcal phage 936 species antibodies against intact phage were utilized. The detection limit was $10^{7} \mathrm{PFU} / \mathrm{mL}$. The most promising technique up till now is the use of DNA probes for the specific detection of 936, c2 and p335 phages. In 2000, Labrie and Moineau succeeded to detect the three species

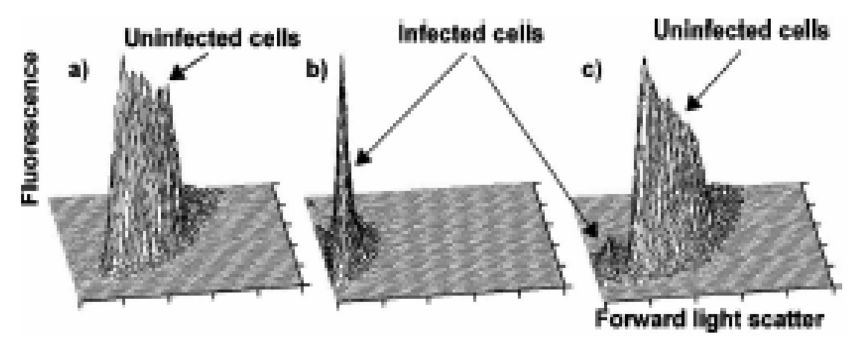

Fig. 4. Flow cytometic analysis for MG1363 strain grown in GM17 with $5 \mathrm{mM} \mathrm{CaCl}_{2}$ (a) before phage incubation, (b) $4 \mathrm{~h}$ after addition of phage, (c) mixture of a $(95 \%)$ and b (5\%) (Michelsen et al., 2007). 
in a single reaction step with a multiplex PCR. The detection limit was $10^{4}-10^{7} \mathrm{PFU} / \mathrm{mL}$. The method was applied on whey and phage lysate. Recently, a multiplex PCR was established that can detect in a single step the 3 common phages, in addition to those attacking the Streptococcus thermophilus and Lactobacillus delbrueckii (Del Rio et al., 2007) (Fig. 5). The detection limit was $10^{3}-10^{4}$ $\mathrm{PFU} / \mathrm{mL}$. It is known that a phage concentration below $10^{5} \mathrm{PFU} / \mathrm{mL}$ in whey or milk is not considered a threat to fermentation (Suarez et al., 2002; McIntyre et al., 1991). This means that a method with a detection limit below $10^{5} \mathrm{PFU} / \mathrm{mL}$ is important for the early intervention in dairy industry.

In 2008, Binetti and his team were successful to detect by the probes against a highly conserved region of the NTP-binding genes in Lactobacillus casei/paracasei phages (Fig. 6). The PCR technique employed was able to detect the phage in milk and cheese whey with a detection limit of $10^{4} \mathrm{PFU} / \mathrm{mL}$. Future works may focus on the possibility to design a multiplex PCR diagnostic kit that combines all the common phages with those recently detected for $L$. casei/paracasei to be the first sensitive and reliable tool that fulfill the dairy industry requirements.

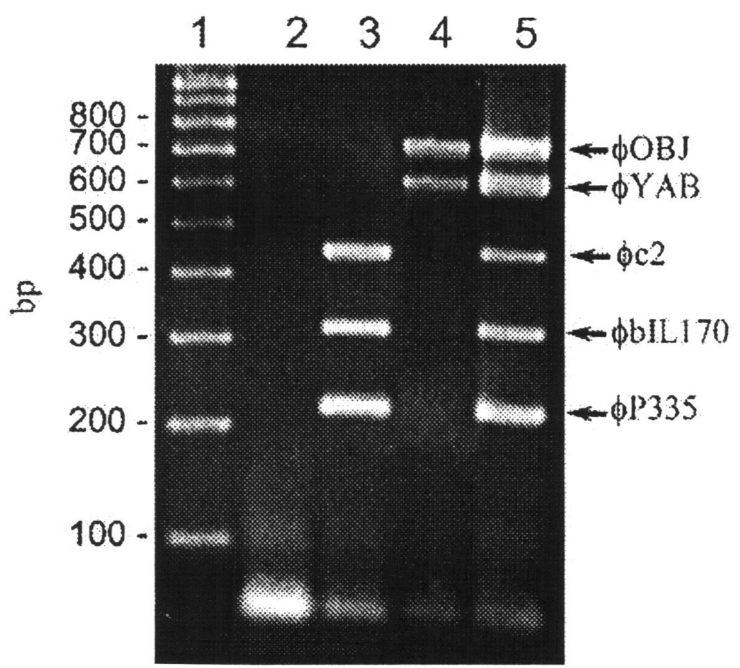

Fig. 5. Multiplex PCR assay with different contaminations of phage species in the same sample. Reactions were performed with phage titres of $10^{6} \mathrm{PFU} \mathrm{mL}{ }^{-1}$ (L. delbrueckii subsp. bulgaricus and $S$. thermophilus phages specis.) $L$. lactis phages: P335 (P335 phage species), bIL170 (936 phage species), and c2 (c2 phage species). YAB represents the $L$. delbrueckii subsp. bulgaricus phage species and OBJ represents the $S$. thermophilus phage species. Lane 1: 100bp molecular marker; Lane 2: negative control (without phages); Lane 3: P335 plus bIL170 and c2; Lane 4: YAB plus OBJ; Lane 5: All five phages (Del Rio et al., 2007).

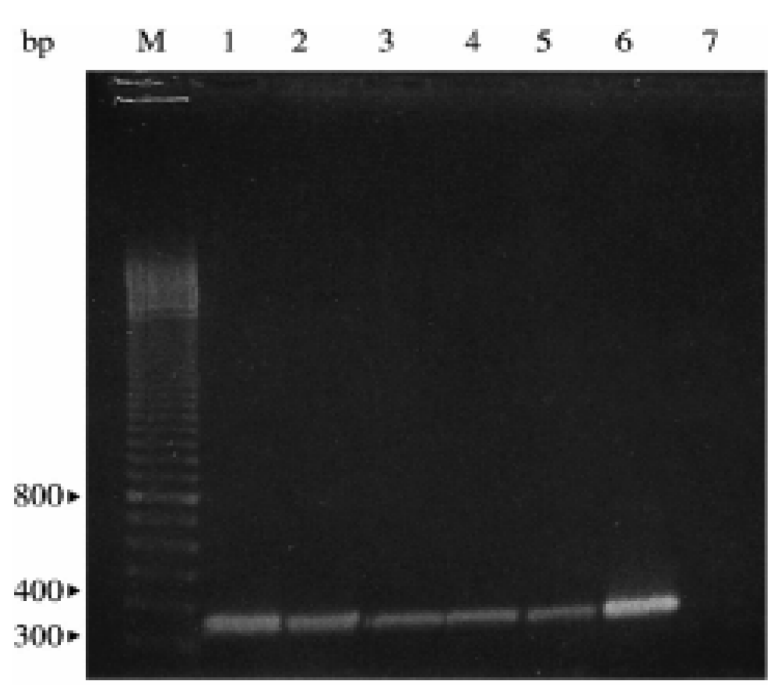

Fig. 6. PCR for detection of $\boldsymbol{L}$. casei/paracasei. Lane M, 100 bp ladder; lane 1, MRS; lane 2, milk; lane 3, yoghurt; lane 4, probiotic fermented milk; lane 5, probiotic cheese whey; lane 6, phage DNA (positive control); lane 7, negative control (Binetti et al., 2008).

\section{Control}

The basic principles to control bacteriophages in cheese plants have been recognized since the early 1940s. Whitehead and Hunter (1945) reviewed on the measures that were used to control slow acid production caused by phage infection is still useful to plant managers today. Even 1945, they already knew that the possible contamination of phage in raw milk was due to tanks, cans and other facilities. But they did not know the lysogency and the possibility of phage arising from starter cultures in raw milk. The knowledge of bacteriophage now vast. Therefore, the researches for developing effective means of eliminating them during cheese making are necessary.

Many approaches have been developed to control phage contamination in cheese plants including hygienic measures, such as chlorination of vats, avoiding aerosol generation and regular atomization of the atmosphere using sterilants (Avsaroglu and Buzrul, 2007; Whitehead, 1953). The use of disinfectants to clean bulk starter tanks and other vessels also has been proposed. The effectiveness of thermal and high-pressure at destroying bacteriophage has been clearly demonstrated (Mûller et al., 2005; Moroni et al., 2002; Zottola and Marth, 1966). Other strategies include production of lactic acid starter in phage inhibitory media and starter culture rotation in cheese production facilities. In recent years, genetic tools have been developed and used to improve the phage resistance of lactic starter cultures. However, these genet- 
ically modified microorganisms have not been approved for use as starter cultures. Besides, the acquired resistance characters are not stable and some phages have already adapted to them, making it unlikely that genetic modifications will lead to the elimination of phage problems. Basically, the methods for controlling phage problems in cheese making include as followed.

\section{Inactivation of bacteriophage by thermal treat- ment}

Some scientists have reported on the heat inactivation of phage. Normal pasteurization temperatures employed in the processing of milk and milk products would not reduce substantially the numbers of bacteriophages present in the milk. In heat treatment, it is important to establish a series of temperature and duration of heating relationships to ensure destruction of the bacteriophage. Too high temperature is not a target because this impairs the properties of milk for cheese-making. Some studies have been reported that heat treatment can cause undesir- able changes (Walstra et al., 1999). For examples, loss of nutrient; the cooked flavor of heated milk results from the liberation of sulfur group (Aboshama et al., 1997). In UHT-heating, whey protein denaturation interrupted rennet coagulation and subsequently the curd became weaker (Schereiber et al., 2000). A reduction of active phage was dependant on temperature (Mûller et al., 2005) (Fig. 7).

\section{Inactivation of bacteriophage by high-pressure treatment}

Inactivation of phage is proportional to both the number of phages and the pressure. Müller (2005) determined the inactivation of strains of Lactococcus lactis phages p001 and p008 which proved that the reduction in colony-forming units started at $200 \mathrm{MPa}$ and the lactococci were completely inactivated at treatments between 400 and 800 Mpa (Fig. 8).

Some evidences proved that the effects of high pressure on bacteriophage by using electron microscopy (Fig. 9) (Moroni et al., 2002). The prolate head and non-contrac-
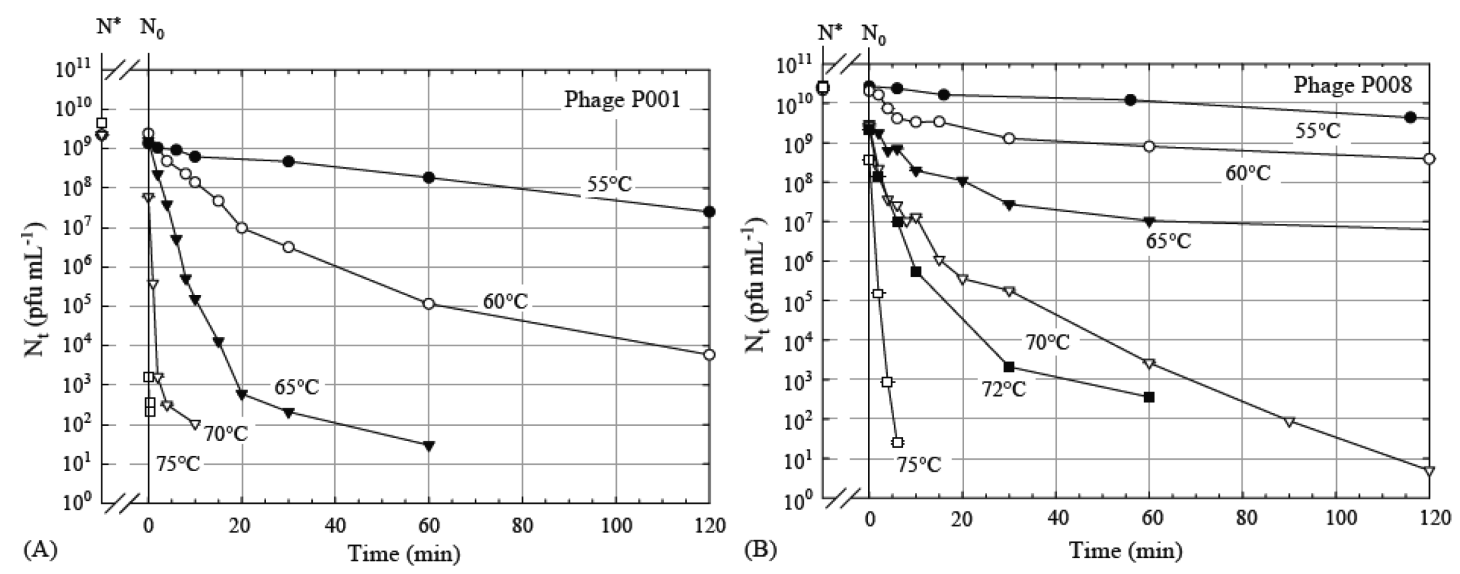

Fig. 7. Effect of heat treatment for $0-120$ min at $55,60,65,70,72$, and $75^{\circ} \mathrm{C}$ on the phage titre of (A) phage $\mathrm{P001}$ and (B) phage P008 in Ca-M17 broth (Mûller et al., 2005).
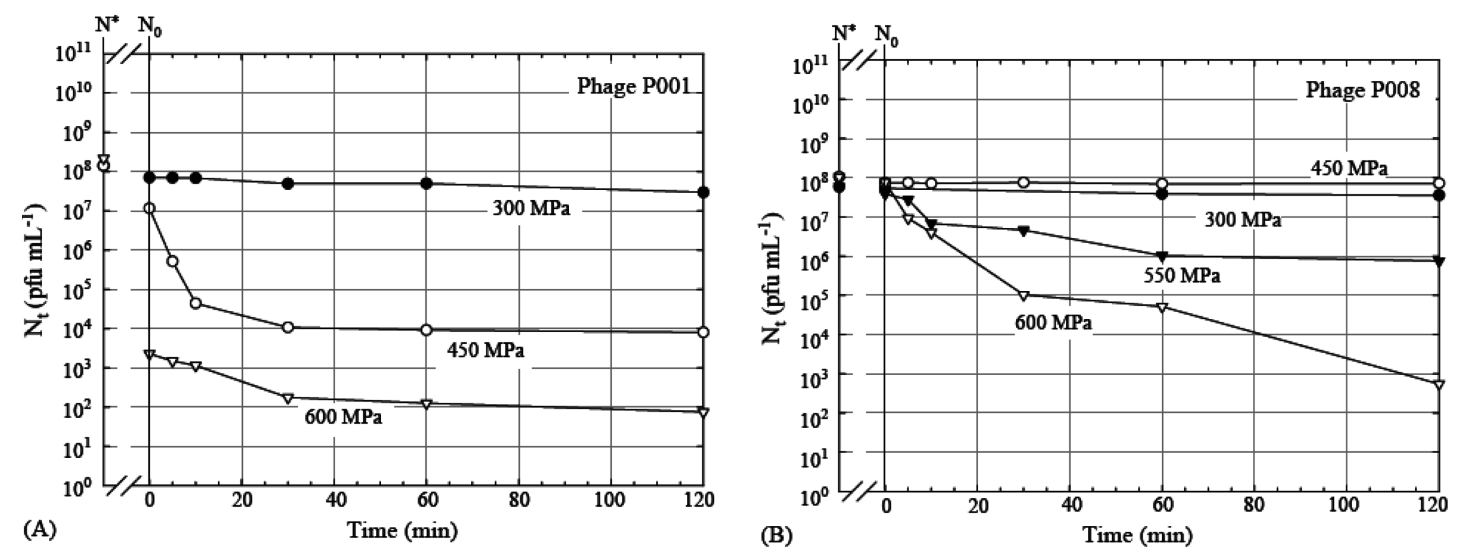

Fig. 8. Effect of high-pressure treatment for $0-120 \mathrm{~min}$ at $25^{\circ} \mathrm{C}$ and $300,450,550$, and $600 \mathrm{Mpa}$ on the phage titre of (A) phage P001 and (B) phage P008 in Ca-M17 broth (Mûller et al., 2005). 

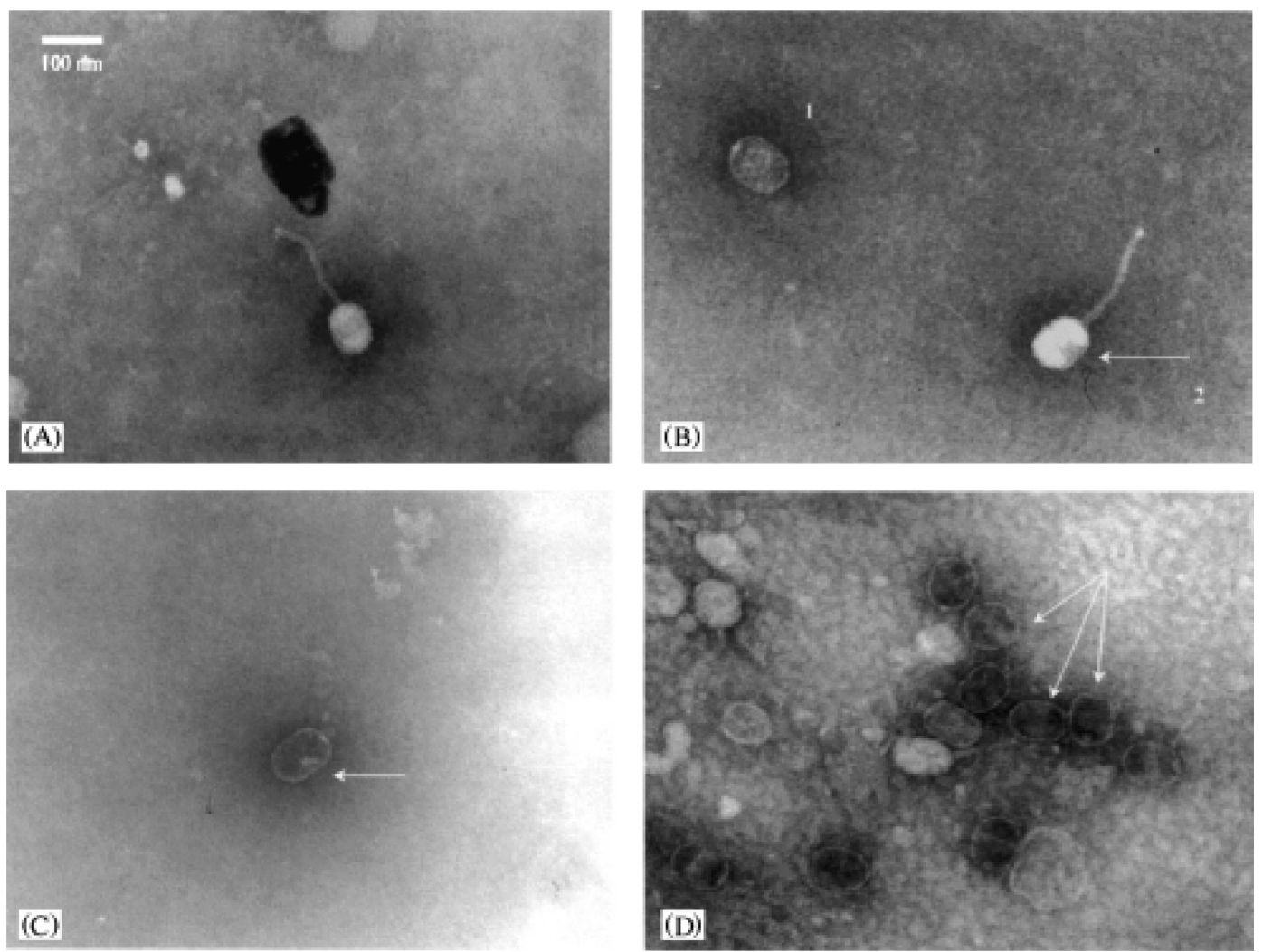

Fig. 9. Electron microscopy of phages treated with dynamic high pressure in PBS. (A) Untreated phage sample, (B) DHP treated sample sowing phage with gap in the head, (C) DHP treated sample showing phage without tail and gap in empty head, and (D) DHP treated sample showing phage without tail and with empty head. Sample B, C and D were treated at 200 Mpa for 5 passes (Moroni et al., 2002).

tile tail of the intact phage were shown in Fig. 9A. Fig. 9B-D shows the effect of treatment at $200 \mathrm{Mpa}$ on the shape of phage. Under high pressure treatment, the coat protein of heads was denatured resulting in partial unfolding, from which genetic material was lost leading to inactivation (Fig. 9C). It was also observed that some phages lost their tail or part of it so they could not attach on host to inject genetic material.

Lopez-Frandino (1996) investigated that pressurization of milk at $300 \mathrm{Mpa}$ improved coagulation characteristics, decreased the coagulation time by $19 \%$ and increased the curd firmness. In other words, the application of high pressure treatment for cheese-making is a good way not only to prevent from bacteriophage, but also to increase the cheese yield.

\section{Inactivation of phage by combined heat and high pressure treatment}

The powers of high pressure and temperature in destroying bacteriophage have been clearly proved as mentioned previously. However, in order to apply practically into dairy manufacturer, the reduction of pressure and temperature are required to minimize undesirable effects but still use every strength point. Therefore, the combination of pressure and temperature has been proposed for this purpose (Fig. 10). In their experiments as

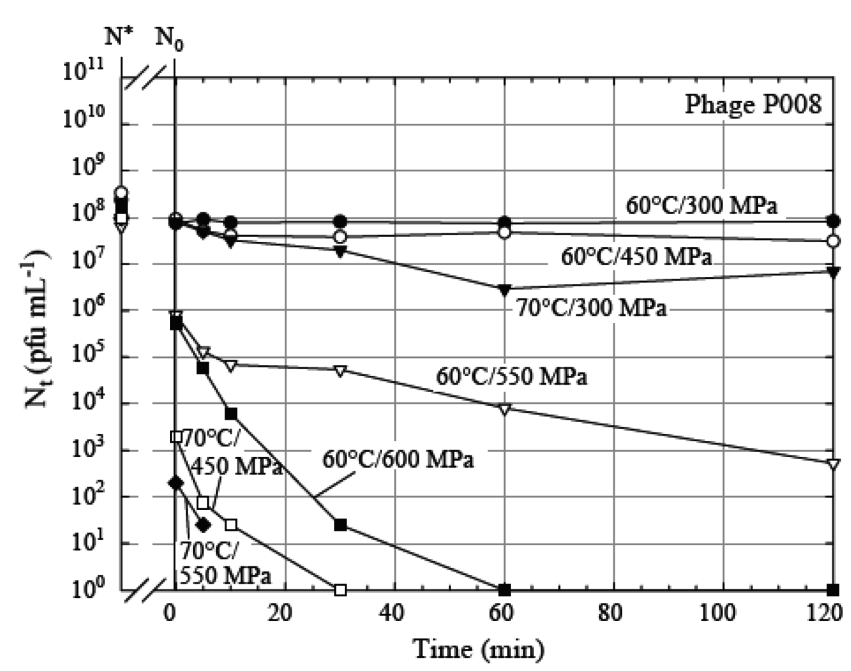

Fig. 10. Effect of combined heat and high-pressure-treatment for 0-120 min at $60^{\circ} \mathrm{C} / 300 \mathrm{Mpa}, 60^{\circ} \mathrm{C} / 300 \mathrm{Mpa}, 60^{\circ} \mathrm{C} /$ $450 \mathrm{Mpa}, 70^{\circ} \mathrm{C} / 300 \mathrm{Mpa}, 60^{\circ} \mathrm{C} / 550 \mathrm{Mpa}$ on the titre of phage P0008 (Mûller et al., 2005). 
shown in Fig. 10, the inactivation increased with increasing pressure at a given time-temperature combination and with increasing temperature at a given pressure-time combination. Interestingly, phage was completely inactivated at $70^{\circ} \mathrm{C}$ and $450 \mathrm{Mpa}$ after $30 \mathrm{~min}$ and $60 \mathrm{~min}$ at $60^{\circ} \mathrm{C}$ and $600 \mathrm{Mpa}$. The reduction by the combination of heat and pressure was much more than at separately each of the same temperatures and pressures. In other words, there was the complement each other between temperature and pressure to propose inhibit bacteriophage. This result demonstrated that selection of temperature and pressure is crucial for phage inactivation.

\section{Inactivation of bacteriophage by thermal and che- mical}

Normally, thermal treatment is directly used for the bacteriophage control but some bacteriophages can be resistant to heat treatment. Therefore, biocides implemented along with high temperature may be useful for complete phage inactivation. Several biocides, such as sodium hypochlorite, ethanol and isopropanol, have been chosen for the phage inactivation. Buzrul reported that the lactococcal bacteriophage was not totally inactivated at $72^{\circ} \mathrm{C}$ for $15 \mathrm{~min}$ or $90^{\circ} \mathrm{C}$ for $5 \mathrm{~min}$ (Table 2). The inactivation capabilities of two alcohols (ethanol and isopropanol) on the viability of phages $\Phi$ pld6434 and $\Phi$ pll62 were investigated. Ethanol at a concentration of $75 \%$ inactivated all the phages for 1 min (Fig. 11). The similar result was also reported for isopropanol for $15 \mathrm{~min}$.

\section{Increasing Phage Resistance of Cheese Starters}

According to Hill (1993), there are three resistance
Table 2. Effectiveness of heat treatments on inactivation of lactococcal bacteriophages (Buzrul et al., 2007)

\begin{tabular}{lcc}
\hline \hline Bacteriophage & $72^{\circ} \mathrm{C}, 15 \mathrm{~min}$ & $90^{\circ} \mathrm{C}, 5 \mathrm{~min}$ \\
\hline Фpld6434 & + & + \\
Фpll105 & + & - \\
Фpll4721 & + & - \\
Фpld6737 & + & + \\
ФPld6636 & + & - \\
Фplc6158 & + & + \\
Фplc6154 & + & + \\
Фpll62 & + & - \\
Фpll356 & - & + \\
Фpll3614 & - & - \\
\hline
\end{tabular}

mechanisms against phage inhibition in lactic acid bacteria. The first is adsorption inhibition due to the incapability of attachment of bacteriophage to the host. The second is the resistance and modification systems which degrade phage DNA and a methylation component for protecting host DNA form digestion. The third is abortive infection where phage multiplication is delayed due to limit their spread to other cells allowing to the bacterial population to proliferate. Among these resistance mechanisms in lactic acid bacteria, abortive infection has been received considerable attentions. Bacterial conjugation techniques to transfer plasmids of phage resistance to starter strains have been demonstrated (Fig. 12, Table 3). Coffey et al. (1998) described the emergence and persistence of a novel phage for Lactococcus lactis subsp lactis DPC4268 by the introduction of pNP40 which encodes abortive infection genes. The bacteriophage-resistant mutant DPC4360 was intact in the presence of phage 4268 and successfully used in Cheddar cheese manufacture.
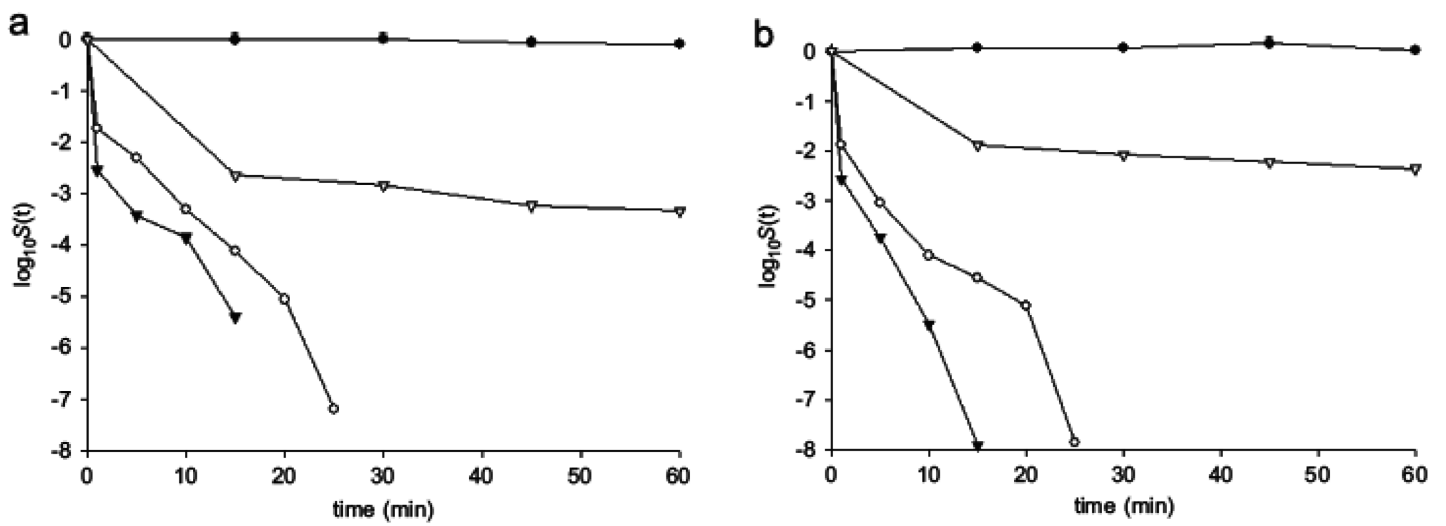

Fig. 11. Inactivation of phage $\Phi$ pld6434 (a) and $\Phi$ pll62 (b) with $10 \%(\odot), 50 \%(\bigcirc), 75 \%(\nabla)$ and $100 \%(\nabla)$ (v/v) of isopropanol. $S(t)$ is the survival ratio, i.e., $S(t)=N(t) / N_{0}$. $N(t)$ and $N_{0}$ are the number of survivors after an exposure time $t$ and initial number of phages $\left(\mathbf{P F U} \mathbf{~ m L}^{-1}\right)$, respectively. The values ate the mean of three replications. The standard deviation for the survival data are less than $0.24 \log _{10}$ (Buzrul et al., 2007). 

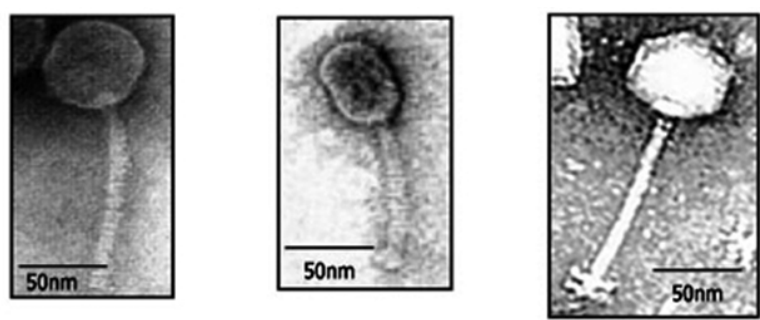

Lactococcal 936 phage Lactococcal c2 phage Lactococcal p335 phage

Fig. 12. Three main lactococcal phage species (Moineau et al., 1999).

\section{Bacteriophage Inhibition Media}

Calcium was important for proliferation of several strains of lactic streptococcus bacteriophage while not required for growth of host bacteria (Shafia and Thompson, 1964; Norman and Nelson, 1953). Therefore, the bacteriophage inhibition media were needed where calcium medium was removed from the starter milk by ion exchange or by using of phosphates to sequester. Calcium medium was referred to as a "phage-resistant medium", so called, PRM/PIM. Nevertheless, application of PRM/ PIM to protect the growth of starters from bacteriophage has some limitations. Some phage could destroy starter cultures even if the calcium was absent (Sozzi, 1972). Other researcher reported that the use of phosphates in PRM/PIM caused injury during metabolism of starter cultures (Ledford and Speck, 1979). Some of problems of PIM have been reported in details (Robertson, 1993).

Some commercial phage inhibitory media have been used for bulk starter production. Some of these media can also be combined with $\mathrm{pH}$ control systems to overcome the drawbacks associated with PRM/PIM as mentioned above in which the $\mathrm{pH}$ control systems were to maintain the level of acidity in the bulk starter medium. Therefore, the damaged cells could be reduced when the $\mathrm{pH}$ droped below 5. Acid development in the growth medium could be controlled by neutralization, which made the starter culture active and increased in cell count. This has been helpful in limitation of the proliferation of phage in the cheese vat. Gaudreau et al. (2006) investigated the effect of $\mathrm{pH}$ control on the phage inactivation. The viable cells of strain NM33-7 under $\mathrm{pH}$ control were obtained $80 \%$ compared just $46 \%$ under without $\mathrm{pH}$ control. This was consisted with the report of Champagne et al. (1995). Sinkoff and Bundus (1983) created the bulk starter media for cheese-making with addition of monoammonium phosphate which improved buffering capacity to keep $\mathrm{pH}$ at 5 for 20 hours during fermentation process.

\section{Minimizing Phage Concentration in Cheese Plant}

Bacteriophages in raw milk proliferate during the fermentation process. Whey contains a large number of phages and may be a primary source of phage infection during cheese making. These phages may directly contaminate throughout the factory by air flow or via whey separation process and subsequently the failure would occur for intermediate and/or final products. Therefore, it is important to minimize the original source of bacteriophage in the plant. The equipment must be cleaned by rinsing with disinfection for several times. Good plant design was reported as an important factor to reduce the concentration of bacteriophage. The location of buildings, prevailing wind, factory drainage, correct process flows, the correct physical separation between raw milk and whey, starter streams, and correct people are important. It was proposed that the concentration of airborne phage infection in the surroundings of cultures could be reduced considerably by separating starter room from factory (Fig. 13) (Whitehead, 1953).

Table 3. List of patented natural phage resistance plasmids or mechanisms in L. lactis

\begin{tabular}{|c|c|c|c|c|c|c|}
\hline \multirow{2}{*}{ Plasmids (systems) } & \multicolumn{3}{|c|}{ Efficiency } & \multirow{2}{*}{ Authors } & \multirow{2}{*}{ Year* } & \multirow{2}{*}{ Patent numbers } \\
\hline & 936 & $\mathrm{c} 2$ & p335 & & & \\
\hline pTN1060 & $10^{-9}$ & $10^{-3}$ & NA & Klaenhammer \& Sanozky & 1989 & US4883756 \\
\hline pTR2030 (AbiA,LlaI) & $10^{-9}$ & $10^{-1}$ & $10^{-9}$ & Klaenhammer et al. & 1990 & US4931396, US5139950 \\
\hline pCI528 (Ads) & $10^{-9}$ & $10^{-9}$ & NA & Daly \& Fitzgerald & 1991 & EP0246909, IE66528 \\
\hline pCI750 (AbiG) & $10^{-9}$ & $10^{-2}$ & NA & & & US5019506 \\
\hline pCI829 (AbiA) & $10^{-9}$ & $10^{-2}$ & NA & & & \\
\hline pFW094 (LlaAI) & $10^{-5}$ & $10^{-4}$ & NA & Josephsen et al. & 1996 & WO9625503 \\
\hline pJW563 (LlaBI) & $10^{-3}$ & $10^{-3}$ & NA & & & \\
\hline pHW393 (LlaDII) & $10^{-4}$ & $10^{-2}$ & $10^{-6}$ & & & \\
\hline pSRQ900 (AbiQ) & $10^{-9}$ & $10^{-9}$ & 1.0 & Moineau et al. & 1999 & US05994118 \\
\hline Chromosome (2227bp) & $10^{-6}$ & 1.0 & $10^{-7}$ & Moineau et al. & 2006 & US7119167B2 \\
\hline
\end{tabular}




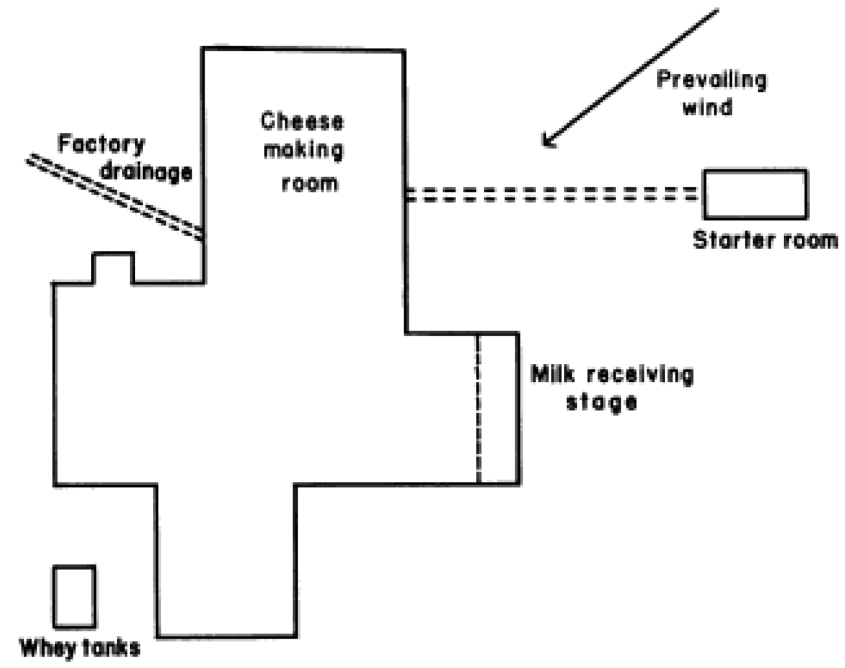

Fig. 13. Example of satisfactory location of starter-preparation building isolated from factory (Whitehead, 1953).

\section{Acknowledgements}

This study was supported by the Brain Korea 21 Project in Seoul, Korea.

\section{References}

1. Aboshama, K. and Hansen, A. P. (1997) Effect of ultra-hightemperature steam sulfur-containing amino acids in milk. $J$. Dairy Sci. 60, 1374-78.

2. Avsaroglu, M. D. and Buzrul, S. (2007) Hypochlorite inactivation kinetics of lactococcal bacteriophages. Food Sci. Technol., 40, 1369-1375.

3. Azaiez, S. R. C., Fliss, I., Simard, R. E., and Moineau, S. (1998) Monoclonal antibodies raised against native major capsid proteins of lactococcal c2-like bacteriophages. Appl. Environ. Microbiol. 64, 4255-4259.

4. Benbadis, L., Faelen, M., Slos, P., Fazel, A., and Mercenier, A. (1990) Characterization and comparison of virulent bacteriophages of Streptococcus thermophilus isolated from yoghurt. Biochimie 72, 855-862.

5. Binetti, A. G., Beatriz, D. R., Martin, M. C., and Alvarez, M. A. (2005) Detection and characterization of Streptococcus thermophilus bacteriophages by use of antireceptor gene sequence. Appl. Environ. Microbiol. 71, 6096-6103.

6. Binetti, A. G., Capra, M. L., Alvarez, M. A., and Reinheimer, J. A. (2008) PCR method for detection and identification of Lactobacillus casei / paracasei bacteriophages in dairy products. Int. J. Food. Microbiol. 124, 147-153.

7. Bissonnette, F., Labrie, S., Deveau, H., Lmaoureux, M., and Moineau, S. (2000) Characterization of mesophilic mixed starter cultures used for the manufacture of aged Cheddar cheese. J. Dairy Sci. 83, 620-627.

8. Braun, V. Jr., Hertwig, S., Neve, H., Geis, A., and Teuber, M. (1989) Taxonomic differentiation of bacteriophages of Lac- tococcus lactis by electron microscopy, DNA-DNA hybridization, and protein profiles. J. Gen. Microbiol. 135, 25512560 .

9. Brüssow, H., Frémont, M., Bruttin, A., Sidoti, J., Constable, A., and Fryder, V. (1994) Detection and classification of Streptococcus thermophilus bacteriophages isolated from industrial milk fermentation. Appl. Environ. Microbiol. 60, 4537-4543.

10. Brüssow, H. and Bruttin, A. (1995) Characterization of a temperate Streptococcus thermophilus bacteriophage and its genetic relationship with lytic phages. Virology 212, 632640.

11. Brüssow, H. and Hendrix R. W. (2002) Phage genomics: small is beautiful. Cell 108, 13-16.

12. Bruttin, A., Desiere, F., D’Amico, N., Guerin, J. P., Sidoti, J., Huni, B., Lucchini, S., and Brussow, H. (1997) Molecular ecology of Streptococcus thermophilus bacteriophage infections in a cheese factory. Appl. Environ. Microbiol. 63, 31443150.

13. Bush, M. L. (2002) Method of inhibiting bacteriophage infections in lactococcal bacteria. Abstract 1637 ADSAASAS Annual Meeting, p. 408.

14. Buzrul, S., Öztürkb, P., Alpa, H., and Akcelik, M. (2007) Thermal and chemical inactivation of lactococcal bacteriophages. LWT - Food Sci. Technol. 40, 1671-1677.

15. Campbell, N. A. and Reece, J. B. (2001). Biology. 6th ed. Benjamin Cummings Press.

16. Capra, M. L., Quiberoni, A., Ackermann, H. W., Moineau, S., and Reinheimer, J. A. (2006) Characterization of a new virulent phage (MLC-A) of Lactobacillus paracasei. J. Dairy Sci. 89, 2414-2423.

17. Champagne, C. P. Piette, M., and Saint-Gelais, D. (1995) Characteristics of lactococcal cultures produced in commercial media. J. Ind. Microbiol. 15, 472-479.

18. Champiat, D., Creuly, C., and Larpent, J. P. (1988) Contrôle de l'activité phagique par dosage de l'ATP chez les streptocoques lactiques mesophiles. Microbiol. Aliment. Nutr. 6, 285-288.

19. Coffey, A. G., Coakley, M., McGarry, A., Fitzgerald, G. F., and Ross, R. P. (1998) Increasing phage resistance of cheese starters: a case study using Lactococcus lactis DPC4268. Letters in Appl. Microbiol. 26, 51-55.

20. Daly, C. (1983) Starter culture developments in Ireland. Ir. J. Food Sci. Technol. 7, 39-48.

21. Daly, C. and Fitzgerald, G. (1991) Plasmids conferring phage insensitivity on bacteria. Patents EP 0246909, IE 66528, US 5019506.

22. Del Rio B., Binetti, A. G., Martin, M. C., Fernandez, M., Magadan, A. H., and Alvarez, M. A. (2007) Multiplex PCR for the detection and identification of dairy bacteriophages in milk. Food Microbiol. 24, 75-81.

23. Duplessis, M., Lévesque, C. M., and Moineau, S. (2006). Characterization of Streptococcus thermophilus host range phage mutants. Appl. Environ. Microbiol. 72, 3036-3041.

24. Dupont, K., Vogensen, F. K., and Josephsen, J. (2005) Detection of lactococcal 936 -species bacteriophages in whey by 
magnetic capture hybridization PCR targeting a variable region of receptor-binding protein genes. J. Appl. Microbiol. 98, 1001-1009.

25. Fayard, B., Haeflinger, M., and Accolas, J. P. (1993) Interaction of temperate bacteriophahges of Strpeococcus salivarius subsp. thermophilus with lysogenic indicators affect phage DNA restriction patterns and host ranges. J. Dairy Sci. 60, 385-399.

26. Forsman, P. and Alatossava, T. (1991) Genetic variation of Lactobacillus delbrueckii subsp. lactis bacteriophage isolated from cheese processing plants in Finland. Appl. Environ. Microbiol. 57, 1805-1812.

27. Gaudreau, H., Fliss, I., and Champagne, C. P. (2006) Stability of autolytic lactococci during starter production and storage in commercial whey-based media. Int. Dairy J. 16, 200206.

28. Heap, H. A. and Jarvi, A. W. (1980) A comparison of prolate and isometric headed lactic streptococcal bacteriophages. $N$. Z. J. Dairy Sci. Technol. 15, 75-81.

29. Henning, D. R., Black, C. H., Sandine, W. E., and Elliker, P. R. (1986) Host range studies of lactic streptococcal bacteriophages. J. Dairy Sci. 51, 16-21.

30. Hill, C. (1993) Bacteriophage and bacteriophage resistance in lactic acid bacteria. FEMS Microbiol. Rev. 12, 87-108.

31. Jarvis, A. W., Fitzgerald, G. F., Mata, M., Mercenier, A., Neve, H., Powell, I. B., Ronda, C., Saxelin, M., and Teuber, M. (1991) Species and type phages of lactococcal bacteriophages. Intervirology 32, 2-9.

32. Jarvis, A. W. (1989) Bacteriophages of lactic acid bacteria. $J$. Dairy Sci. 72, 3406-3428.

33. Josephsen, J. and Neve, H. (2004) Lactic acid bacteria: microbiological and functional aspects. 3th ed. Marcel Dekker, Inc.

34. Josephsen, J., Petersen, A., Neve, H., and Nielsen, E. W. (1999) Development of lytic Lactococcus lactis bacteriophages in a Cheddar cheese plant. Int. J. Food Microbiol. 50, 163-171.

35. Josephsen, J., Nyengaard, N. R., Vogensen, F. K., and Madesen, A. (1996) Plasmid-derived type II restriction-modification systems from Lactococcus lactis. PCT W09625503.

36. Kivi, S., Peltomaki, T., Luomala, K., and Sarimo, S. S. (1987) Some properties of Streptococcus thermophoilus bacteriophages. Folia Microbiol. 32,101-106.

37. Klaenhammer, T. and Sanozky, R. (1989) pTN1060, a conjugal plasmid and derivatives thereof that confer phage resistance to group N streptococci. US Patent 4883756.

38. Klaenhammer, T., Sanozky, R., and Steenson, L. (1990) pTR2030, a conjugal plasmid and derivatives thereof that confer phage reisistance to group N streptococci. Patents US 4931396, US 5139950.

39. Labrie, S. and Moineau, S. (2000) Multiple PCR for detection and identification of lactococcal bacteriophages. Appl. Environ. Microbiol. 66, 987-994.

40. Lawrence, R. C., Heap, H. A., and Limsowtin, G. (1978) Symposium: Research and development trends in natural cheese manufacturing and ripening. J. Dairy Sci. 61, 1181-
1191.

41. Le Marrec, C., van Sinderen, D., Walsh, L., Stanley, E., Vlegels, E., Moineau, S., Heinze, P., Fitzgerald, G., and Fayard, B. (1997) Streptococcus thermophilus bacteriophages can be divided into two distinct groups based on mode of packaging and structural protein composition. Appl. Environ. Microbiol. 63, 3246-3253.

42. Ledford, R. A. and Speck, M. L. (1979) Injury of lactic streptococci by culturing in media mechanisms high phosphates. J. Dairy Sci. 62, 781-784.

43. Lopez-Fandino, R., Carrascosa, A. V., and Olano, A. (1996) The effects of high pressure on whey protein denaturation and cheese-making properties of raw milk. J. Dairy Sci. 79, 929-936.

44. Madera, C., Monjardin, C., and Suarez, J. E. (2004) Milk contamination and resistance to processing conditions determine the fate of Lactococcus lactis bacteriophages in dairies. Appl. Environ. Microbiol. 70, 7365-7371.

45. Mata, M. and Ritzenthaler, P. (1988) Present state of lactic acid bacteria phage taxonomy. Biochimie 70, 395-399.

46. McGrath, S., Fitzgerald, G. F., and Sinderen, D. V. (2004a) Cheese chemistry, physics and microbiology. 3th ed. Elsevier, Ltd.

47. McGrath, S., Fitzgerald, G. F., and Sinderen, D. V. (2004b) The impact of bacteriophage genomics. Curr. Opin. Biotechnol. 15, 94-99.

48. McGrath, S., Neve, H., Seegers, J. F. M. L., Eijlander, R., Vegge, C. S., Brøndsted, L., Heller, K. J., Fitzgerald, G. F., Vogensen, F. K., and Sinderen, D. (2006) Anatomy of a lactococcal phage tail. J. Bacteriol. 188, 3972-3982.

49. McIntyre, K., Heap, H. A., Davey, G. P., and Limsowtin, G. K. Y. (1991) The distribution of lactococcal bacteriophage in the environment of cheese manufacturing plant. Int. Dairy J. 1, 183-197.

50. Michelsen, O., Cuesta-Dominguez, A., Albrechtsen, B., and Jensen, P. R. (2007) Detection of bacteriophage-infected cells of Lactococcus lactis by using flow cytometry. Appl. Environ. Microbiol. 73, 7575-7581.

51. Moineau, S., Borkaev, M., Holler, B. J., Walker, S. A., Kondo, J. K., Vedamuthu, E. R., and Vanderbergh, P. A. (1993) Production of monoclonal antibodies against the major capsid protein of the lactococcus bacteriophage ul36 and development of an enzyme-linked immunosorbent assay for direct phage detection in whey and milk. Appl. Environ. Microbiol. 59, 2034-2040.

52. Moineau S., Bouchard J., and Dion. L. (2006) Fragment of Lactococcus lactis plasmid conferring antiphage activity and uses thereof. US Patent 7119167B2.

53. Moineau, S., Emond, E., Walker, S. A., Vedamuthu, E. R., and Kondo, J. K. (1999) DNA encoding phage resistance protein. US Patent 05994118.

54. Moineau, S., Fortier, J., Ackermann, H. W., and Pandian, S. (1992) Characterization of lactococcal bacteriophages from Quebec cheese plants. Can. J. Microbiol. 38, 875-882.

55. Moineau, S., Borkaev, M., Holler, B. J., Walker, S. A., Kondo, J. K., Vedamuthu, E. R., and Vandenbergh, P. A. 
(1996) Isolation and characterization of lactococcal bacteriophages from cultured buttermilk plants in the United States. J. Dairy Sci. 79, 2104-2111.

56. Moroni, O., Jean, J., Autret, J., and Fliss, I. (2002) Inactivation of lactococcal bacteriophages in liquid media using dynamic high pressure. Int. Dairy J. 12, 907-913.

57. Müller, M., Rauscher, M. T., and Hinrichs, J. (2005) Inactivation of bacteriophages by thermal and high-pressure treatment. Int. Dairy J. 15, 777-784.

58. Nelson, D., Schuch, R., Chahales, P., Zhu, S., and Fischetti, V. A. (2006) A multimeric bacteriophage lysin. Proc. Natl. Acad. Sci. USA 103, 10765-10770

59. Neve, H., Krusch, U., and Teuber, M. (1989) Classification of virulent bacteriophages of Sreptococcus salivarius subsp thermophilus isolated from yogurt and swiss-type cheese. Appl. Microbiol. Biotechnol. 30, 624-629.

60. Nichols, A. A. and Hoyle, M. (1949) Bacteriophage in typing lactic streptococci. J. Dairy Res. 16, 167-208.

61. Norman, N. P. and Nelson, F. E. (1953) Role of calcium and related ions in proliferation of lactic Streptococcus bacteriophage. J. Bacteriol. 66, 508-516.

62. Powell, I. B., Arnold, P. M., Hillier, A. J., and Davidson, B. E. (1989) Molecular comparison of prolate- and isometricheaded bacteriophages of lactococci. Can. J. Microbiol. 35, 860-866.

63. Prescott, L., Harley, J., and Klein, D. (2002) Microbiology. 5th ed. Mcgraw Hill Publishing Co., pp. 348-361.

64. Prevots, F., Mata, M., and Ritzenthaler, P. (1990) Taxonomic differentiation of 101 lactococcal bacteriophages with unusually large genomes. Appl. Environ. Microbiol. 56, 21802185.

65. Quiberoni, A., Auad, L., Binetti, A. G., Sua'rez, V. B., Reinheimer, J. A., and Raya, R. R. (2003) Comparative analysis of Streptococcus thermophilus bacteriophages isolated from a yogurt industrial plant. Food Microbiol. 20, 461-469.

66. Robertson, P. (1993) Are phage-inhibitory media necessary? UW Dairy Pipeline 5, 1-11

67. Sanlibaba, P. and Akçelik, M. (2005) Classification of virulent lactococcal bacteriophages based on protein composition and restriction endonuclease analysis. Turk. J. Vet. Anim. Sci. 29, 865-871.

68. Schereiber, R. and Hinrichs, J. (2000) Rennet coagulation of heated milk concentrates. Lait 80, 33-42.
69. Sellars, R. L. (1981) Fermented dairy foods. J. Dairy Sci. 64, 1070-1076.

70. Shafia, F. and Thompson, T. L. (1964) Calcium ion requirement for proliferation of bacteriophage $\mu-4$. J. Bacteriol. 88 , 293-296.

71. Sinkoff, B. A. and Bundus, R. H. (1983) Bulk starter media. US Patent 4,402,986.

72. Sozzi, P. T. (1972) Calcium requirements of lactic starter phages. Milchwissenschaft 27, 503-506.

73. Suarez, V. B., Quiberoni, A., Binetti, A. G., and Reinheimer, J. A. (2002) Thermophilic lactic acid bacteria phages isolated from Argentinian dairy industries. J. Food Prot. 65, 1597-1604.

74. Svenson, U. and Christansson, A. (1991) Methods for phage monitoring. Bull. Int. Dairy Fed. 263, 29-39.

75. Svensson, U. K. (1994) Conductimetric analysis of bacteriophage infection of two groups of bacteria in DL-lactococcal starter culture. J. Dairy Sci. 77, 3524-3531.

76. Szcepañska, A. K., Hejnowicz, M. S., Kolakowski, P., and Barcowski, J. (2007) Biodiversity of Lactococcus lactis bacteriophages in Polish dairy environ. Acta Polonica 54,151158.

77. Tseng, Y. C. and Hicks, C. L. (2008) Simplified petrifilm assay for lactococcus phage. Abstract W76 ADSA-ASAS Annual Meeting, pp. 217-218.

78. Valles, E. (1955) Sur l'emploi de differents indicateurs d'oxydo-réduction pour l'étude des bactériophages des streptocoques lactiques. Lait 35, 241-258.

79. Walstra, P., Geurts, T. J., Noomen, A., Jellema, A., and Van Boekel, M. (1999) Dairy technology: principles of milk properties and processes. Dekker. New York

80. Whithead, R. H. (1953) Bacteriophage in cheese manufacture. J. Dairy Sci. 17, 109-123.

81. Whitehead, H. R. and Hunter, G. J. E. (1945) Bacteriophage infection in cheese manufacture. J. Dairy Res. 14, 64-80.

82. Wilkowske, H. H., Nelson, F. E., and Parmelee, C. E. (1954) Serological classification of bacteriophages active against lactic streptococci. Appl. Microbiol. 2, 243-249.

83. Zottola, E. A. and Marth. E. H. (1966) Thermal inactivation of bacteriophages active against lactic streptococci. J. Dairy Sci. 49, 1338-1342.

(Received 2008.8.29/Revised 1st 2008.10.29, 2nd 2008.11.20/Accepted 2008.11.24) 